\title{
Karakteristik Pasien Transfusi Darah dengan Inkompatibilitas Crossmatch di UTD RSUP Dr M Djamil Padang
}

\author{
Desta Purwati ${ }^{1}$, Zelly Dia Rofinda ${ }^{2}$, Husni $^{2}$
}

\begin{abstract}
Abstrak
Transfusi adalah pelayanan kesehatan yang bagaikan pisau bermata dua. Disatu sisi terkadang merupakan satu-satunya cara penyelamatan pasien, tetapi disisi lain transfusi juga berisiko fatal. Transfusi yang aman dapat diperoleh dengan melakukan uji kompatibilitas diantaranya crossmatch. Inkompatibilitas pada crossmatch dipengaruhi banyak faktor. Tujuan: Menyajikan data karakteristik pasien transfusi darah dengan inkompatibilitas crossmatch di UTD RSUP DR.M.Djamil Padang Periode Juli-Desember 2018. Metode: Penelitian ini adalah penelitian deskriptif. Hasil pemeriksaan dengan inkompatibilitas crossmatch dikumpulkan dan dilihat karakteristik pasien berupa jenis kelamin, umur,, golongan darah, diagnosis, tipe inkompatibilitas dan riwayat transfusi. Hasil: Inkompatibilitas terbanyak didapatkan pada perempuan $(61,6 \%)$, usia $>50$ tahun $(54,36 \%)$, golongan darah $A(37,86 \%)$, diagnosis infeksi $(26,21 \%)$, tipe inkompatibilitas minor $(87,3 \%)$ dan dengan riwayat transfusi berulang $(58,25 \%)$. Simpulan: Inkompatibilitas crossmatch tidak dipengaruhi jenis kelamin tetapi dipengaruhi riwayat transfusi sebelumnya.
\end{abstract}

Kata kunci: inkompatibilitas crossmatch, karakteristik pasien, transfusi darah

\section{Abstract}

The transfusion is a health service that is like a double-edged knife. On the one hand, it is sometimes the only way to save a patient's life, but on the other hand, transfusion is also at risk of being fatal. Safe transfusion can be obtained by conducting a compatibility test, including crossmatch. Crossmatch incompatibility is influenced by many factors. Objectives: To described the characteristic of blood transfusion patients with crossmatch incompatibility at UTD RSUP DR. M. Djamil Padang from July-December 2018. Methods: This was a descriptive study, the result of crossmatch incompatibility were collected and the characteristic of patients such as gender, age, blood type, diagnosis, type of incompatibility, history of transfusion were described. Results: Most crossmatch incompatibility was found in women (61.16\%), age $>50$ years (54.36\%), blood type $A 37.86 \%$, diagnosis of infection (26,21\%), type of minor incompatibility (87.37\%), with history of multiple transfusion (58.25\%). Conclusion: Crossmatch incompatibility is not affected by sex but is influenced by a history of previous transfusions.

Keywords: blood transfusion, crossmatch incompatibility, patient characteristic

Affiliasi penulis: ${ }^{1}$ Program Pendidikan Dokter Spesialis Patologi Klinik Fakultas Kedokteran, Universitas Andalas, Padang, Indonesia. ${ }^{2}$ Bagian Patologi Klinik, Fakultas Kedokteran, Universitas Andalas/ RSUP Dr. M. Djamil Padang, Indonesia.

Korespondensi: destapatklin2016@gmail.com telp: 081273974565

\section{PENDAHULUAN}

Transfusi darah adalah bagian dari pelayanan kesehatan yang semakin lama semakin sering dilakukan dan merupakan bagian dari pengobatan modern sejak awal abad ke-21. Berbagai keadaan di masyarakat, seperti meningkatnya kecelakaan lalu lintas, operasi besar, terapi suportif keganasan serta semakin banyaknya kasus katastropik pengguna darah yang harapan hidupnya semakin meningkat, menyebabkan pemakaian darah semakin meningkat pula. ${ }^{1,2,3}$

Transfusi merupakan pelayanan kesehatan yang bagaikan pisau bermata dua, pada satu sisi transfusi terkadang merupakan satu-satunya cara yang dapat menyelamatkan jiwa pasien, tetapi disisi lain transfusi juga berisiko fatal. ${ }^{1,3}$ Kesalahan tahap pretransfusi 
menyebabkan transformasi transfusi darah dari live saving menjadi live threatening ${ }^{4}$. Penyebab terbanyak reaksi transfusi fatal adalah pemberian eritrosit inkompatibel $\mathrm{ABO}^{5}$.

Transfusi harus diberikan atas indikasi yang kuat dengan persiapan baik. Salah satu persiapan yang harus dilakukan sebelum transfusi adalah uji kompatibilitas, diantaranya terdiri dari pemeriksaan golongan darah (ABO dan Rhesus), skrining antibodi, serta reaksi silang (crossmatch). Uji kompatibilitas bertujuan untuk mencegah reaksi transfusi hemolitik yang dimediasi imun, dibutuhkan pemahaman yang baik tentang antigen yang diekspresikan eritrosit pada donor dan resipien sebelum transfuse. ${ }^{1,6,7,8,9}$

Prinsip dasar transfusi modern adalah memberikan manfaat sebanyak mungkin dengan risiko minimal atau tanpa risiko terhadap resipien. ${ }^{10}$. Transfusi darah sebaiknya dihindari jika tidak banyak bermanfaat. ${ }^{11}$ Crosmatch (dilambangkan dengan XM) merupakan tahap pretransfusi yang sangat penting dan uji terakhir terhadap kompatibilitas $A B O$ antara eritrosit donor dan plasma resipien untuk memastikan tidak ada antibodi yang terdapat dalam plasma resipien. ${ }^{6,7,12,13}$

Berdasarkan standar dari American Association of Blood Bank (AABB), crossmatching didefinisikan sebagai suatu pemeriksaan yang menggunakan metode yang mampu menunjukkan inkompatibilitas sistem ABO dan adanya antibodi signifikan terhadap antigen eritrosit. ${ }^{12}$ Pemeriksaan ini untuk mengetahui apakah antigen eritrosit donor sesuai dengan antibodi di serum resipien (crossmatch mayor) dan antigen eritrosit resipien terhadap antibodi di serum donor (crossmatch minor). ${ }^{14}$ Pemeriksaan crossmatch dilakukan terhadap pasien dengan kemungkinan besar mendapat transfusi darah eritrosit, merupakan pemeriksaan in-vitro untuk memprediksi reaksi in-vivo saat eritrosit donor ditransfusikan. ${ }^{15,16}$ Tidak adanya hemolisis atau aglutinasi pada semua fase maka darah donor boleh ditransfusikan. ${ }^{17}$

Pemeriksaan crossmatch dapat dilakukan secara serologik dan elektronik/komputerisasi. Uji pretransfusi adekuat dan kompatibel tidak menjamin umur eritrosit yang ditransfusikan normal, tetapi kepatuhan terhadap prosedur uji pretransfusi dan unit donor akan memastikan transfusi aman. ${ }^{18,19}$
Penemuan metoda gel atau column aglutination test system telah membawa perubahan yang besar. $^{20}$ Prinsip metoda gel adalah sistem pengayakan. ${ }^{21}$ Hasil autokontrol positif harus dilanjutkan dengan pemeriksaan Direct Antiglobulin Test (DAT). ${ }^{22}$ Interpretasi hasil crossmatch dengan metoda gel, dapat dilihat pada Gambar 1.

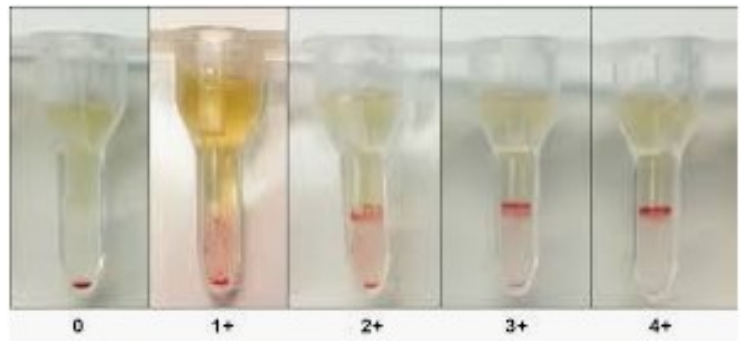

Gambar 1. Hasil reaksi aglutinasi metode gel ${ }^{23}$

Penelitian retrospektif di Bank Darah Rumah sakit (BDRS) RSUP Dr. Wahidin Sudirohusodo Makassar dengan mengambil data rekam medis pasien dari Juni 2013-Juni 2014 didapatkan inkompatibilitas crossmatch terbanyak pada perempuan (50,7\%), umur $>17$ tahun (83,6\%), diagnosis penyakit infeksi $(36,2 \%)$, golongan darah $\mathrm{B}(32,9 \%)$, Rhesus positif (100\%) dengan tipe inkompatibilitas minor $(81,2 \%)$ dan pasien tanpa riwayat transfusi $(97,7 \%){ }^{24}$

Penelitian ini bertujuan untuk melihat karakteristik pasien transfusi darah dengan inkompatibilitas crossmatch pada Unit Transfusi Darah (UTD) RSUP Dr. M. Djamil Padang periode Juli sampai Desember 2018.

\section{METODE}

Penelitian deskriptif ini dilakukan di UTD RSUP Dr. M Djamil Padang mulai dari Juli sampai Desember 2018. Populasi adalah seluruh pasien dengan hasil inkompatibilitas crossmatch baik mayor maupun minor. Sampel penelitian adalah bagian dari populasi yang memenuhi kriteria inklusi dan eksklusi. Kriteria inklusi adalah pasien dengan hasil inkompatibilitas crossmatch mayor dan atau minor. Kriteria eksklusi adalah pasien dengan data yang tidak lengkap pada pencatatan UTD dan rekam medis RSUP Dr. M. Djamil Padang. Derajat aglutinasi diperiksa dengan metoda gel. Hasil ukur dinilai positif satu, positif dua, 
positif tiga atau positif empat. Data dianalisis, diolah dan disajikan dalam bentuk tabel distribusi. Penelitian ini sudah disetujui oleh Komite Etik Penelitian Kesehatan RSUP Dr. M. Djamil Padang Nomor: 371/KEPK/2019.

\section{HASIL}

Penelitian dilakukan secara deskriptif terhadap 103 pasien inkompatibilitas crossmatch yang diperiksa di UTD RSUP Dr. M. Djamil Padang dari Juli sampai Desember 2018. Sampel penelitian adalah bagian populasi yang memenuhi kriteria inklusi dan eksklusi. Parameter yang diperiksa meliputi jenis kelamin, umur, golongan darah, diagnosis, tipe inkompatibilitas, diagnosis, riwayat transfusi. Data yang didapat, diolah dan disajikan dalam bentuk Tabel 1.

Tabel 1. Karakteristik subjek penelitian

\begin{tabular}{lr}
\hline \multicolumn{1}{c}{ Variabel } & Jumlah (\%) \\
\hline Jumlah sampel (103) & \\
Jenis Kelamin: & \\
Laki - laki & $40(38,4)$ \\
Perempuan & $63(61,6)$ \\
Umur: & \\
<6 bulan & $2(1,94)$ \\
6 bulan - 50 tahun & $45(43,68)$ \\
>50 tahun & $56(54,36)$ \\
Diagnosis & \\
Kelainan hematologi & $26(25,24)$ \\
Keganasan nonhematologi & $15(14,56)$ \\
Infeksi & $27(26,21)$ \\
Metabolik Endokrin & $8(7,26)$ \\
Kongenital & $2(1,94)$ \\
Gangguan ginjal & $17(16,50)$ \\
Gangguan hepar & $5(4,85)$ \\
Diagnosis lain & $2(1,94)$ \\
Golongan Darah : & \\
Golongan Darah A & $39(37,86)$ \\
Golongan Darah B & $23(22,33)$ \\
Golongan Darah O & $25(24,27)$ \\
Golongan Darah AB & $16(15,5)$ \\
Tipe Inkompatibilitas & \\
Inkompatibilitas mayor dan minor & $4(3,88)$ \\
Inkompatibilitas mayor & $90(8,73)$ \\
Inkompatibilitas minor & $(41,27)$ \\
Rransfusi &
\end{tabular}

Jumlah sampel sebanyak 103 orang, inkompatibilitas crossmatch terbanyak ditemukan pada perempuan yaitu 63 orang $(61,6 \%)$, umur $>50$ tahun dan diagnosis terbanyak yaitu infeksi 27 orang $(26,21 \%)$.

Inkompatibilitas terbanyak ditemukan pada golongan darah A yaitu 39 orang $(37,86 \%)$, tipe inkompatibilitas minor sebanyak 90 orang $(87,37 \%)$ dan mempunyai riwayat transfusi 60 orang $(58,25 \%)$.

\section{PEMBAHASAN}

Subjek penelitian berjumlah 103 orang, didapatkan inkompatibilitas crossmatch pada laki-laki $38,83 \%$ dan wanita $61,16 \%$. Hal ini mengindikasikan bahwa tidak ada pengaruh gender yang mempengaruhi inkompatibilitas crossmatch. Usia terbanyak terdapat pada usia $>50$ tahun, hal ini disebabkan permintaan darah terbanyak terjadi pada usia tesebut. Pasien dengan riwayat transfusi ditemukan lebih tinggi, karena transfusi berulang dapat menstimulasi respon imun sekunder dan peningkatan titer antibodi setelah transfusi.

Tipe inkompatibilitas yang banyak ditemukan pada penelitian ini adalah inkompatibilitas crossmatch minor. Hasil ini sama dengan penelitian Irawaty et al (2016) mendapatkan inkompatibilitas crossmatch minor sebanyak $81,2 \%{ }^{24}$ Inkompatibilitas mayor dan minor yang didapatkan pada penelitian ini $3,88 \%$, hal ini kemungkinan disebabkan oleh darah donor Direct Coombs test (DCT) positif atau serum pasien mengandung alloantibodi. Sikap yang harus diambil yaitu: lakukan pemeriksaan DCT pada donor, bila positif ganti darah donor, dan lakukan skrining dan identifikasi antibodi pada serum pasien serta ulang crossmatch dengan unit darah yang tidak mengandung antigen yang sesuai dengan antibodi yang ditemukan. Bila skrining dan identifikasi antibodi tidak bisa, pemeriksaan dirujuk atau lakukan crossmatch ulang dengan beberapa unit darah donor lain $^{12}$.

Penelitian ini mendapatkan inkompatibilitas mayor $8,73 \%$, beberapa kemungkinan yang bisa menyebabkan hal ini, diantaranya adalah golongan darah $\mathrm{ABO}$ pasien atau donor salah, serum pasien mengandung antibodi $\mathrm{ABO}$, terdapat alloantibodi dalam serum pasien yang bereaksi dengan eritrosit 
donor. Sikap yang harus dilakukan yaitu: periksa ulang golongan darah $\mathrm{ABO}$ dan konfirmasi ketepatan identitas pasien, lakukan pemeriksaan subgroup dengan menelusuri riwayat ransfusi dan transplantasi pada pasien, lakukan skrining dan identifikasi antibodi pada serum pasien dan ulang crossmatch dengan unit darah yang tidak mengandung antigen yang sesuai dengan antibodi yang ditemukan. Bila skrining dan identifikasi antibodi tidak bisa dilakukan, crossmatch ulang dengan beberapa unit darah donor yang lain sampai didapatkan mayor negative. ${ }^{12}$

Penelitian ini mendapatkan inkompatibilitas crossmatch terbanyak ditemukan pada kasus infeksi. Hasil ini sama dengan penelitian oleh Irawaty et al (2016), sebanyak 36,2\% inkompatibilitas crossmatch disebabkan oleh infeksi. ${ }^{24}$

\section{SIMPULAN}

Inkompatibilitas crossmatch terbanyak didapatkan pada perempuan $(61,16 \%)$, usia $>50$ tahun $(54,36 \%)$, golongan darah A $(37,86 \%)$, diagnosis infeksi $(26,21 \%)$, tipe inkompatibilitas minor $(87,37 \%)$ dan dengan riwayat tranfusi berulang $58,25 \%$.

\section{SARAN}

Dibutuhkan penelitian lebih lanjut untuk mengetahui tipe alloantibodi dan autoantibodi pada pasien dengan inkompatibilitas crossmatch.

\section{DAFTAR PUSTAKA}

1. Dalimoenthe NZ. Diskrepansi golongan darah ABO. Edisi ke-1. Bandung: Divisi Hematologi klinik. Dep/SMF Patologi Klinik FK. Unpad/RSHS; 2014.

2. Chinnabhandar V, Choudhary VP, Nagar $S$, Sachdeva A. Blood component therapy. Dalam: Sachdeva A, editor (penyunting). Practical pediatric hematology. Edisi ke-2. New Delhi: Jaypee; 2012. hlm 181-2.

3. Wynn R, Bhat R, Monagle P, editor (penyunting). Pediatric hematology, a practical guide. United Kingdom: Cambridge University Press; 2017.

4. Gehrie EA, Chandler J, Synder EL. Clinical and technical aspect of blood administration. Dalam: Simon TL, McCullough J, Snyder EL, Solheim BG, Strauss RG, editor (penyunting). Rossi's principles of transfusion Medicine, Edisi ke-5. USA: Willey Blackwell; 2016. hlm.23-8.

5. McCullough $\mathrm{J}$, editor (penyunting). Transfusion medicine. Edisi-4. UK. Wiley Blackwell; 2017.

6. Zundel WB. Pretransfusion testing. Dalam: Harmening DM, editor (penyunting). Modern blood banking \& transfusion practice. Edisi ke-6. Philadelphia: FA Davis company; 2012. hlm. 241 59.

7. Nayak R, Rai S, Gupta A, editor (penyunting). Essentials in hematology and clinical pathology. India: Jaypee Brothers Medical Publishers $(P)$ Ltd; 2012.

8. Quillen K. Blood groups, pretransfusion testing, and red blood cell transfusion. Dalam: Rifai $\mathrm{N}$, Horvath AR, Twitter CT, editor (penyunting). Clinical chemistry and molecular diagnostics. Edisi ke-6. USA: Elsevier; 2018. hlm.1743.e15.

9. Reid ME, Lomas-Francis C Erythrocyte antigens and antibodies. Dalam: Kaushansky K, Lichtman MA, Prchal JT, Levi MM, Press OW, Burns LJ, Caligiuri MA, editor (penyunting). Williams hematology. Edisi ke-9. USA: McGraw Hill; 2016. hlm. 2329-51.

10. Mehdi SR, editor (penyunting). Essential of blood banking, a handbook for students of Blood Banking and Clinical Residents, Edisi ke-2. India:Jaypee Brothers Medical Publisher (P) Ltd; 2013.

11. Triulzi DJ, Yazer $\mathrm{MH}$, Waters JH. Patient blood management. Dalam: Simon TL, McCullough J, Snyder EL, Solheim BG, Strauss RG, editor (penyunting). Rossi's principles of transfusion medicine. Edisi ke-5. USA: wiley Blackwell; 2016. hlm.13-22.

12. Mulyantari NK, Putu Sutirta Yasa IW. Uji cocok serasi (crossmatching). Dalam: Atmaja J, editor (penyunting). Laboratorium pratransfusi update. Denpasar: Udayana University Press; 2016. hlm. 82.

13. Elkins M, Davenport R, Mintz PD. Transfusion medicine. Dalam: Mc-Pherson RA, Pincus MR, Bluth $\mathrm{MH}$, Bock JL, Browne WB, Hutchinson RE, Karcher DS, Lifshitz, Davis M, Rao AK, Unger ER, Woods GL, editor (penyunting). Henry's clinical diagnosis and management by laboratory Methods. Edisi ke-23. USA: Elsevier; 2017. hlm.735-40. 
14. Castillo B, Dasgupta A, Klein K, Tint H, Wahed A, editor (penyunting). Transfusion medicine for pathologist: A comprehensive review for board preparation, certification, and clinical practice. USA: Elsevier; 2018.

15. Young C, Denesiuk L. Pretransfusion and compatibility testing. Dalam: Johns G, Cohen LM, Zundel W, Blessing EG, Denesiuk L, editor (penyunting). Clinical laboratory blood banking and transfusion medicine principles and practice. USA: Pearson; 2015. hlm.113-14.

16. Dzieczkowski J, Tiberghien P, Anderson KC. Transfusion biology and therapy. Dalam: Jameson JL, Fauci AS, Kasper DL, Hauser SL, Longo DL, Loscalzo J, editor (penyunting). Harrison's: Principles of Internal Medicine. Edisi ke-20. USA: McGrawHill Education; 2018. hlm. 809-15.

17. Stoe M. Pretransfusing testing. Dalam: Quinley ED, editor (penyunting). Immunohematology principles \& practice. Edisi ke-3. Washington DC: Lippincott Williams \& Wilkins, Wolters Kluwer; 2011. hlm. 107-14.

18. Howard PR, editor (penyunting). Basic \& applied concepts of blood banking and transfusion practices. Edisi ke- 4. Missori: ELSEVIER; 2017.

19. Wolf LA. Pretransfusion Testing. Dalam: Harmening DM, editor (penyunting). Modern blood banking \& transfusion practices. Edisi ke-7. Philadelphia: FA Davis; 2019.hIm.257-61.

20. Yazer $\mathrm{MH}$, Delaney M. Pretransfusion testing and selection of red cell products for transfusion. Dalam: Murphy MF, Roberts DJ, Yazer MH, editor (penyunting). Practical transfusion medicine. Edisi ke-5. UK: Wiley Blackwell; 2017.hlm.58-62.

21. Barnes BC. Blood bank application of antigenantibody reaction, Chapter 3. Dalam: Johns G, Cohen LM, Zundel W, Blessing EG, Denesiuk L, editor (penyunting). Clinical laboratory blood banking and transfusion medicine principles and practice. USA: Pearson; 2015.hlm.37-48.

22. Walker PS, Hamilton JR. Identification of antibodies to red cell antigen. Dalam: Fung MK, Grossman BJ, Hillyer CD, Westhoff CM, editor (penyunting). Technical manual. Edisi ke-18.USA. AABB; 2014. hlm.391-417.

23. Wajiha. Image column agglutination (gel card) technique for crossmatching. 2012. Agustus (diunduh 20 Juli 2020). Tersedia dari: https:// www.pathlabtalk.com.

24. Irawaty, Rachmawaty AM, Arif M. Characteristic of crossmatch types in comaptibility testing on diagnosis and blood types using gel method. Indonesia Clinical pathology and Medical Laboratory. 2016; 23(1):36-41. 